Federal Reserve Bank of Dallas

Globalization and Monetary Policy Institute

Working Paper No. 39

http://www.dallasfed.org/assets/documents/institute/wpapers/2009/0039.pdf

\title{
State-Dependent Pricing, Local-Currency Pricing, and Exchange Rate Pass-Through ${ }^{*}$
}

\author{
Anthony Landry \\ Federal Reserve Bank of Dallas
}

September 2009

\begin{abstract}
This paper presents a two-country DSGE model with state-dependent pricing as in Dotsey, King, and Wolman (1999) in which firms price-discriminate across countries by setting prices in local currency. In this model, a domestic monetary expansion has greater spillover effects to foreign prices and foreign economic activity than an otherwise identical model with time-dependent pricing. In addition, the predictions of the state-dependent pricing model match the business-cycle moments better than the predictions of the time-dependent pricing model when driven by monetary policy shocks.
\end{abstract}

JEL codes: F41, F42

\footnotetext{
* Anthony Landry, Research Department, Federal Reserve Bank of Dallas, Research Department, 2200 N. Pearl Street, Dallas, TX, 75201. 214-922-5831. Anthony.Landry@dal.frb.org. This paper is a revised and rewritten version of Research Department Working Paper 0706. I would like to thank Marianne Baxter, Russell Cooper, Michael Devereux, Simon Gilchrist, Michel Juillard, Robert G. King, Sylvain Leduc, two anonymous referees, and seminar participants at Boston University, the Federal Reserve Bank of Dallas, and the $47^{\text {th }}$ Annual Meeting of the Société Canadienne de Science Économique for helpful comments and suggestions. The views in this paper are those of the author and do not necessarily reflect the views of the Federal Reserve Bank of Dallas or the Federal Reserve System.
} 


\section{Introduction}

What are the implications of monetary policy shocks when exchange rate passthrough to prices is sluggish and incomplete? To answer this question, the openeconomy macroeconomic literature has focused on dynamic general equilibrium models with nominal rigidities in which monopolistic firms price-discriminate across countries by setting prices in local currency. This mechanism acts to limit the passthrough from exchange rate changes to foreign prices and largely insulates foreign economies from domestic monetary policy shocks. Good examples of these models include Betts and Devereux (2000), Chari et al. (2002), and Kollmann (2001). However, a much criticized but standard element of this literature is the exogenously imposed timing of the opportunity firms have for nominal price adjustments.

I address this critique by developing a two-country version of the dynamic general equilibrium model with state-dependent pricing (SDP) from Dotsey, King, and Wolman (1999) in which firms price-discriminate across markets by setting price in local currency. ${ }^{1}$ In the model, firms pay a single menu cost to have the opportunity to change their domestic and export prices. The SDP pricing structure implies that the degree of price rigidity depends on the state of the economy: Over the business cycle, this pricing structure generates discrete and occasional price adjustments by firms in light of variations in demand and cost conditions. Those changes in economic environment affect not only the intensive margin-the level of price adjustment undertaken by price-adjusting firms-but also the extensive margin-the fraction of firms actively engaged in price adjustment. I find that a domestic monetary expansion generates larger spillover effects to foreign prices and foreign economic activity under the SDP model, than a similar model with time-dependent pricing (TDP) because of the interplay between the intensive and extensive margins.

In local-currency pricing models, a domestic monetary expansion affects firms' profits on exported goods via two channels: a depreciation of the dollar, and an increase in marginal cost generated by higher domestic demand. On one hand, the dollar depreciation increases profits as firms get more dollar for every unit sold in the foreign market. On the other, the increase in marginal cost shrinks profits. In the TDP model, these two effects roughly balance out over the expected horizon of price rigidities. Therefore, firms barely adjust export prices following a domestic

\footnotetext{
${ }^{1}$ In my previous work (Landry 2009), I look at the implications of monetary policy shocks in a two-country model with state-dependent pricing in which the law-of-one price holds.
} 
monetary expansion. In the SDP model, firms have the ability to change their prices in light of demand and cost conditions. On impact, the first effect dominates and firms decide to lower their export prices to attract foreign demand. However, the second effect takes over after a few quarters and firms start raising export prices. Over the business cycle, these export price movements generate fluctuations in foreign expenditure without any actions in foreign monetary policy. This result contradicts the current wisdom and has important implications for the design of international monetary policy in a local-currency pricing environment.

I take the model to the data by choosing parameter values to replicate the trade relationship between the U.S. and Canada. I introduce two features to the model to better capture the business-cycle moments observed in the data. First, I add variable demand elasticity, following the work of Kimball (1995), to generate inertia in prices and adjustment fractions. Second, I introduce investment with variable capital utilization, following the work of Baxter and Farr (2005). Investment is needed to generate the relative volatility of consumption to output, while variable capital accumulation is needed to smooth investment demand and trade flows. Overall, the SDP model's predictions match the business-cycle moments better than the predictions of the TDP model when driven by monetary policy shocks.

This paper is related to the development of other local-currency pricing SDP models. For example, Gopinath et al. (2009) study the endogenous currency choice firms face when setting prices, while Gopinath and Itskhoki (2009) study the relation between the frequency of price adjustment and the level of exchange rate passthrough. Floden and Wilander (2006) focus on exchange rate pass-through and the volatility of import prices. These three studies use a partial equilibrium approach where firms' decisions are driven by productivity or exchange rate shocks. In contrast, I use a general equilibrium approach to study the international business-cycle transmission of monetary shocks. The nature of the dynamic general equilibrium approach implies fluctuations in prices and exchange rate pass-through that affects foreign economic conditions.

Section 2 of this paper describes the open-economy SDP model. Section 3 presents the model's solution and parameterization. Section 4 discusses the model's implications. First, I analyze the endogenous evolution of price distributions in response to a domestic monetary expansion, describe the way these distributions influence exchange rate pass-through and international economic activity, and contrast the implications of the SDP model with a corresponding TDP model that is 
used as a reference case because of its popularity in the current literature. Then, I look at the business-cycle implications of the model in which the world economy experiences shocks to the U.S. and Canadian money stocks. I also examine the sensitivity of my findings by varying assumptions about the SDP model benchmark. Section 5 concludes.

\section{The Model}

The world economy consists of two countries. Each country is populated by a representative household, a continuum of monopolistic firms, and a monetary authority. Households purchase goods produced in both countries for consumption and investment, and supply labor and capital on a competitive basis. Firms rent labor and capital from the domestic market to produce goods. They can price-discriminate across countries and set prices in local currency. The distinctive feature of the model is that in each period, firms can change their prices by paying a menu cost. If a firm decides to pay the menu cost, it has the opportunity to change its domestic and export prices. Once prices are set, firms must satisfy demand.

In what follows, each variable is represented by a country-i.e. $i, j=1,2$ for Country 1 (U.S.) and Country 2 (Canada)-and time subscripts. When three subscripts are present, the first denotes the country of production, the second denotes the country of consumption or investment, and the third denotes time.

\subsection{Households}

Households are identical across countries except for the local bias introduced in consumption and investment. They make consumption $c_{i, t}$ and labor supply $n_{i, t}$ decisions to maximize expected lifetime utility:

$$
E_{t} \sum_{t=0}^{\infty} \beta^{t}\left(\frac{1}{1-\sigma} c_{i, t}^{1-\sigma}-\frac{\chi}{1+\eta} n_{i, t}^{1+\eta}\right), \text { for } i=1,2 .
$$

The momentary utility function is separable in consumption and leisure. The parameter $\beta$ represents the discount factor, $\sigma$ represents the intertemporal elasticity of substitution, and $\eta$ represents the elasticity of labor supply.

The households' optimal consumption allocations are defined as a constant elasticity of substitution (CES) composite of domestic and imported consumption, such 
that

$$
\begin{aligned}
& c_{1, t}=\left(\left(1-\theta_{1}\right)^{\frac{1}{\gamma}} c_{1,1, t}^{\frac{\gamma-1}{\gamma}}+\theta_{1}^{\frac{1}{\gamma}} c_{2,1, t}^{\frac{\gamma-1}{\gamma}}\right)^{\frac{\gamma}{\gamma-1}}, \\
& c_{2, t}=\left(\left(1-\theta_{2}\right)^{\frac{1}{\gamma}} c_{2,2, t}^{\frac{\gamma-1}{\gamma}}+\theta_{2}^{\frac{1}{\gamma}} c_{1,2, t}^{\frac{\gamma-1}{\gamma}}\right)^{\frac{\gamma}{\gamma-1}} .
\end{aligned}
$$

In these equations, the parameters $\theta_{i}$ for $i=1,2$ represent the steady-state shares of imports into consumption, and $\gamma$ represents the elasticity of substitution between domestic and imported goods. The goal of the household is to minimize expenditure such that equation (2) holds. The solution to the minimization problem yields the following optimal consumption quantities:

$$
\begin{array}{ll}
c_{1,1, t}=\left(1-\theta_{1}\right)\left(\frac{P_{1,1, t}^{P}}{P_{1, t}^{C}}\right)^{-\gamma} c_{1, t}, & c_{2,1, t}=\theta_{1}\left(\frac{P_{2,1, t}^{P}}{P_{1, t}^{C}}\right)^{-\gamma} c_{1, t}, \\
c_{2,2, t}=\left(1-\theta_{2}\right)\left(\frac{P_{2,2, t}^{P}}{P_{2, t}^{C}}\right)^{-\gamma} c_{2, t}, & c_{1,2, t}=\theta_{1}\left(\frac{P_{1,2, t}^{P}}{P_{2, t}^{C}}\right)^{-\gamma} c_{2, t},
\end{array}
$$

where $P_{i, t}^{C}$ for $i=1,2$ represents the aggregate consumption prices, and $P_{i, j, t}^{P}$ for $i=1,2$ represents the aggregate producer prices.

Households also choose an optimal amount of capital through investment $i_{i, t}$. Investment decisions are made following the capital accumulation equations:

$$
k_{i, t+1}=\left(1-\delta\left(u_{i, t}\right)\right) k_{i, t}+\phi\left(\frac{i_{i, t}}{k_{i, t}}\right) k_{i, t} \text { for } i=1,2,
$$

where $k_{i, t}$ denotes the capital stocks, $\delta$ the depreciation function with $\delta^{\prime}>0$ and $\delta^{\prime \prime}<0, u_{i, t}$ the utilization rates of capital, and $\phi$ the capital adjustment cost with $\phi^{\prime}>0$ and $\phi^{\prime \prime}<0$. The households' optimal investment allocations are identical to the consumption allocations (2).

Given these optimal choices, aggregate consumption and investment prices are a weighted sum of domestic and imported goods prices:

$$
\begin{aligned}
& P_{1, t}^{c}=P_{1, t}^{i}=\left(\left(1-\theta_{1}\right)\left(P_{1,1, t}^{P}\right)^{1-\gamma}+\theta_{1}\left(P_{2,1, t}^{P}\right)^{1-\gamma}\right)^{\frac{1}{1-\gamma}}, \\
& P_{2, t}^{c}=P_{2, t}^{i}=\left(\left(1-\theta_{2}\right)\left(P_{2,2, t}^{P}\right)^{1-\gamma}+\theta_{2}\left(P_{1,2, t}^{P}\right)^{1-\gamma}\right)^{\frac{1}{1-\gamma}} .
\end{aligned}
$$

The benchmark economy features complete risk pooling to isolate the role of SDP. This implies that households can freely reallocate risk through a complete set of state-contingent nominal bonds $b_{i, t}$ and corresponding stochastic discount factor 
$D_{t}$, such that $E_{t}\left[D_{t+1} b_{i, t+1}\right]=\sum_{s_{t+1}} \rho\left(s_{t+1} \mid s_{t}\right) D\left(s_{t+1} \mid s_{t}\right) b_{i}\left(s_{t+1}\right)$, where $\rho\left(s_{t+1} \mid s_{t}\right)$ denotes the probability of the state of nature $s_{t+1}$ given $s_{t}$. The households also receive capital payments $Q_{i, t}$ from capital services, nominal wages $W_{i, t}$ from labor services, and a series of dividend payments $Z_{i, t}$ from firms. In each country, capital services $x_{i, t}$ are the product of the capital stock and the utilization rate. The sequence of intertemporal budget constraints can be represented in terms of aggregates as

$$
P_{i, t}^{c} c_{i, t}+P_{i, t}^{i} i_{i, t}+E_{t}\left[D_{t+1} b_{i, t+1}\right] \leq b_{i, t}+Q_{i, t} x_{i, t}+W_{i, t} n_{i, t}+Z_{i, t} \text { for } i=1,2
$$

The problem for households is then to choose consumption, investment, labor, and portfolio holdings to maximize lifetime utility (1) subject to a sequence of intertemporal budget constraints (6) and allocation of time. The maximization problem implies that the ratios of marginal utilities of consumption $\lambda_{i, t}$ are equalized across countries, or $q_{t}=\kappa \cdot \lambda_{2, t} / \lambda_{1, t}$. The real exchange rate is defined as $q_{t}=$ $S_{t} \cdot\left(P_{2, t}^{C} / P_{1, t}^{C}\right)$, where $S_{t}$ is the dollar price of one unit of foreign currency, and $\kappa$ reflects initial wealth differences.

Finally, the level of nominal aggregate demand is governed by a cash-in-advance constraint $M_{i, t}=P_{i, t}^{c} c_{i, t}+P_{i, t}^{i} i_{i, t}$ for $i=1,2$, along with money supply rules.

\section{$2.2 \quad$ Firms}

A continuum of monopolistically competitive firms is located on the unit interval and indexed by $z$ in each country. At any date $t$, a firm is identified by its current prices and its current menu cost of price adjustment $\xi_{i, t}(z) \in[0, \bar{B}]$. The menu cost is denominated in labor hours and drawn from a time-invariant distribution $G\left(\xi_{i, t}\right)$ common across all firms in country $i$. Since the indices $z$ are uncorrelated over time, and there are no other state variables attached to individual firms, price-adjusting firms in the same country find it optimal to charge a common price in each market. I restrict the analysis to positive steady-state inflation rates so that the benefit of price adjustment becomes infinitely large as the number of periods for which the price has been fixed grows. Given that the support of the distribution $G\left(\xi_{i, t}\right)$ is finite, there is a finite fraction of vintages in each country $F_{i}$, a vintage being a measure of firms with common domestic and export prices. 


\subsubsection{Firms' demand and Aggregate Prices}

I introduce variable demand elasticity following the work of Kimball (1995), as in the open-economy model of Bouakez (2005), Gopinath et al. (2009), Gopinath and Itskhoki (2009), Gust et al. (2006). In contrast to a Dixit-Stiglitz demand, variable demand elasticity makes it more costly for adjusting firms to get their prices out of line with prices set by other firms. However, as opposed to TDP models in which the timing of price adjustment is fixed, SDP and variable demand elasticity increase the interaction between firms: Variable demand elasticity makes it desirable for firms to keep their prices similar, while SDP makes it feasible for them to do so.

Consider the following expenditure-minimization problem for each country:

$$
\min _{d_{i, j, t}(z)} \int_{0}^{1} P_{i, j, t}(z) d_{i, j, t}(z) d z \quad \text { subject to } \quad \int_{0}^{1} \Gamma\left(\frac{d_{i, j, t}(z)}{d_{i, j, t}}\right) d z=1 \text { for } i, j=1,2,
$$

where

$$
\Gamma\left(\frac{d_{i, j, t}(z)}{d_{i, j, t}}\right)=\frac{1}{(1+\varphi) \varrho}\left[(1+\varphi)\left(\frac{d_{i, j, t}(z)}{d_{i, j, t}}\right)-\varphi\right]^{\varrho}-\left[1+\frac{1}{(1+\varphi) \varrho}\right]
$$

In these equations, $d_{i, j, t}$ represents the demand for goods produced in country $i$ and purchased in country $j$. Each firm produces a differentiated product such that $P_{i, j, t}(z)$ identifies the price charged by an individual firm with relative demand $d_{i, j, t}(z) / d_{i, j, t}$. The demand aggregator $\Gamma$ is such that an aggregate producer price index $P_{i, j, t}^{P}$ holds in each market. The demand aggregator $\Gamma$ is an increasing and concave function reflecting diminishing demand elasticity and is defined over the parameters $\varphi$ and $\varrho$. The parameter $\varphi$ determines the curvature of the demand function, while $\varrho$ determines the elasticity of demand at average product prices. A nice property of this specification is that the Dixit-Stiglitz aggregator is a special case represented by $\varphi=0$.

The demand aggregator defines firms' relative demand as a function of individual and aggregate prices, and of the curvature parameters of the demand function

$$
\frac{d_{i, j, t}(z)}{d_{i, j, t}}=f\left(\frac{P_{i, j, t}(z)}{P_{i, j, t}^{P}}, \varphi, \varrho\right) \text { for } i, j=1,2 .
$$

Finally, the aggregate producer prices follow a weighted sum of prices over individual firm demand ratios

$$
P_{i, j, t}^{P}=\int_{0}^{1} P_{i, j, t}(z)\left(\frac{d_{i, j, t}(z)}{d_{i, j, t}}\right) d z \text { for } i, j=1,2 .
$$




\subsubsection{Production}

Supply is demand driven, and production by an individual firm is the sum of demand in the domestic and export markets:

$$
y_{i, t}(z)=y_{i, i, t}(z)+y_{i, j, t}(z) \text { for } i, j=1,2,
$$

where

$$
y_{i, j, t}(z)=f\left(\frac{P_{i, j, t}(z)}{P_{i, j, t}^{P}}, \varphi, \varrho\right) \cdot d_{i, j, t} \text { for } i, j=1,2 .
$$

Equation (12) illustrates that production by an individual firm depends on its price relative to other domestic firms (PPI) and on the market's demand. Market demand is determined by the sum of consumption and investment demand such that $d_{i, j, t}=c_{i, j, t}+i_{i, j, t}$ for $i, j=1,2$.

Labor used for price adjustment is denoted $n_{i, t}^{a}(z)$, and labor used for production is denoted $n_{i, t}^{y}(z)$. Total labor employed by a firm is thus $n_{i, t}^{a}(z)+n_{i, t}^{y}(z)=n_{i, t}(z)$. Production by an individual firm is

$$
y_{i, t}(z)=x_{i, t}^{1-\varsigma}(z) \cdot n_{i, t}^{\varsigma}(z) \text { for } i, j=1,2 \text {. }
$$

where $\varsigma$ represents the labor share in production.

\subsubsection{Pricing Policy}

In both SDP and TDP frameworks, the firms' optimal decision can be represented using a dynamic programming approach: Given the level of demand, the current menu cost of price adjustment, the current real price, the prevailing real capital service, and the real wage, individual firms decide whether or not to adjust their prices with respect to a state vector $s_{t}$. Accordingly, each firm $z$ that has changed its price $f$ periods ago has a real value function of the form

$$
\begin{gathered}
v\left(p_{i, i, t}^{C}, p_{i, j, t}^{C} \xi_{i, t}(z) \mid s_{t}\right)= \\
\max \left\{\begin{array}{c}
v_{i, f, t}=\pi\left(p_{i, i, f, t}^{C}, p_{i, j, f, t}^{C} \mid s_{t}\right)+\beta E_{t} \Lambda_{i, t, t+1} v\left(p_{i, i, f+1, t+1}^{C}, p_{i, j, f+1, t+1}^{C}, \xi_{i, t+1}(z) \mid s_{t+1}\right), \\
v_{i, 0, t}=\max _{\widehat{p}_{i, i, t}^{C}, \widehat{p}_{i, j, t}^{C}} \pi\left(\widehat{p}_{i, i, t}^{C}, \widehat{p}_{i, j, t}^{C} \mid s_{t}\right)+\beta E_{t} \Lambda_{i, t, t+1} v\left(\widehat{p}_{i, i, t+1}^{C}, \widehat{p}_{i, j, t+1}^{C} \xi_{i, t+1}(z) \mid s_{t+1}\right)-w_{i, t} \xi_{i, t}(z)
\end{array}\right\} \\
\text { for } i, j=1,2, i \neq j,
\end{gathered}
$$

with the value if the individual firm does $v_{i, 0, t}$ or does not $v_{i, f, t}$ adjust, and the optimal prices chosen by adjusting firms $\widehat{p}_{i, i, f, t}^{C}=P_{i, i, f, t} / P_{i, t}^{C}$, and $\widehat{p}_{i, j, f, t}^{C}=S_{t} P_{i, j, f, t} / P_{i, t}^{C}$ for $i=1$ and $j=2$ and $\widehat{p}_{i, j, f, t}^{C}=P_{i, j, t} / S_{t} P_{i, t}^{C}$ for $i=2$ and $j=1$. Both the optimal 
and current real prices are relative to domestic CPI, which are prices used in firms' decisionmaking. $\Lambda_{i, t, t+1}=\lambda_{i, t+1} / \lambda_{i, t}$ denotes the ratio of future to current marginal utility and is the appropriate discount factor for future real profits. Finally, real profits is defined as $\pi\left(p_{i, i, t}^{C}, p_{i, j, t}^{C} \mid s_{t}\right)=\left(p_{i, i, f, t}^{C}-\psi_{i, t}\right) y_{i, i, t}+\left(p_{i, j, f, t}^{C}-\psi_{i, t}\right) y_{i, j, t}$ where $\psi_{i, t}$ represents marginal cost. Therefore, firms' profits are affected by the prices received for units sold domestically and abroad and by marginal cost.

Equation (14) shows that the firm must weigh the current and future benefits of adjusting its prices against the status quo. Price-adjusting firms set prices optimally and choose cost-minimizing levels of input. Firms that decide not to adjust prices satisfy demand while choosing inputs to minimize costs. In this model, the fraction of firms in country $i$ that choose to adjust is $\alpha_{i, j, t}$. These fractions are determined by the menu cost of marginal firms being just equal to the value gained such that ${ }^{2}$

$$
\xi\left(\alpha_{i, f, t}\right)=\frac{v_{i, 0, t}\left(s_{t}\right)-v_{i, f, t}\left(s_{t}\right)}{w_{i, t}\left(s_{t}\right)} \text { for } i=1,2 .
$$

Finally, the dynamic program (14) implies that the optimal price satisfies a firstorder equation balancing pricing effects on current and expected future profits. As part of an optimal plan, price-adjusting firms choose prices that satisfy

$$
\begin{aligned}
& 0=\frac{\partial \pi\left(p_{i, i, t}^{C}, p_{i, j, t}^{C} \mid s_{t}\right)}{\widehat{p}_{i, i, t}^{C}}+\beta E_{t}\left[\Lambda_{i, t, t+1} \cdot \frac{\partial v\left(\widehat{p}_{i, i, t}^{C}, \widehat{p}_{i, j, t}^{C} \xi_{i, t}(z) \mid s_{t}\right)}{\partial \widehat{p}_{i, i, t}^{C}}\right] \text { for } i=1,2 . \\
& 0=\frac{\partial \pi\left(p_{i, i, t}^{C}, p_{i, j, t}^{C} \mid s_{t}\right)}{\widehat{p}_{i, j, t}^{C}}+\beta E_{t}\left[\Lambda_{i, t, t+1} \cdot \frac{\partial v\left(\widehat{p}_{i, i, t}^{C}, \widehat{p}_{i, j, t}^{C} \xi_{i, t}(z) \mid s_{t}\right)}{\partial \widehat{p}_{i, j, t}^{C}}\right] \text { for } i, j=1,2, i \neq j .
\end{aligned}
$$

Iterating these first-order equations (16) forward, firms' nominal optimal prices $\widehat{P}_{i, j, t}$ can be expressed as an explicit function of current and expected future variables

$$
\begin{aligned}
\widehat{P}_{i, i, t} & =\frac{\sum_{f=0}^{F_{i}-1} \beta^{f} E_{t}\left[\Omega_{i, f, t, t+f} \cdot \Lambda_{i, t, t+f} \cdot \epsilon_{i, i, f, t+f} \cdot \psi_{i, t+f} \cdot P_{i, i, t+f}^{P} \cdot d_{i, i, f, t+f}\right]}{\sum_{f=0}^{F_{i}-1} \beta^{f} E_{t}\left[\Omega_{i, f, t, t+f} \cdot \Lambda_{i, t, t+f} \cdot\left(\epsilon_{i, i, f, t+f}-1\right) \cdot\left(P_{i, i, t+f}^{P} / P_{i, t+f}^{C}\right) \cdot d_{i, i, j, t+f}\right]} \text { for } i=1,2, \\
\widehat{P}_{1,2, t} & =\frac{\sum_{f=0}^{F_{1}-1} \beta^{f} E_{t}\left[\Omega_{1, f, t, t+f} \cdot \Lambda_{1, t, t+f} \cdot \epsilon_{1,2, f, t+f} \cdot \psi_{1, t+f} \cdot P_{1,2, t+f}^{P} \cdot d_{1,2, f, t+f}\right]}{\sum_{f=0}^{F_{1}-1} \beta^{f} E_{t}\left[\Omega_{1, f, t, t+f} \cdot \Lambda_{1, t, t+f} \cdot\left(\epsilon_{1,2, f, t+f}-1\right) \cdot\left(S_{t+f} P_{1,2, t+f}^{P} / P_{1, t+f}^{C}\right) \cdot d_{1,2, j, t+f}\right]}, \\
\widehat{P}_{2,1, t} & =\frac{\sum_{f=0}^{F_{2}-1} \beta^{f} E_{t}\left[\Omega_{2, f, t, t+f} \cdot \Lambda_{2, t, t+f} \cdot \epsilon_{2,1, f, t+f} \cdot \psi_{2, t+f} \cdot P_{2,1, t+f}^{P} \cdot d_{2,1, f, t+f}\right]}{\sum_{f=0}^{F_{2}-1} \beta^{f} E_{t}\left[\Omega_{2, f, t, t+f} \cdot \Lambda_{2, t, t+f} \cdot\left(\epsilon_{2,1, f, t+f}-1\right) \cdot\left(P_{2,1, t+f}^{P} / S_{t+f} P_{2, t+f}^{C}\right) \cdot d_{2,1, j, t+f}\right]},
\end{aligned}
$$

where $\Omega_{i, f, t, t+f}$ represents the probability of nonadjustment from $t$ to $t+j$ and $\epsilon_{i, j, f, t+f}$ denotes the elasticity of demand for the individual firm. The optimal prices charged by price-adjusting firms have a fixed markup over real marginal cost

\footnotetext{
${ }^{2}$ These are continuous functions on the unit interval $0 \leq \alpha_{i, f, t} \leq 1$ such that the real labor cost of a marginal firm is $\xi\left(\alpha_{i, f, t}\right)$ if the fraction of firms $\alpha_{i, f, t}$ are adjusting prices. Thus, (15) describes the endogenous fractions of price-adjusting firms in each country.
} 
if the demand elasticity and the aggregate prices are expected to be constant over time. These optimal pricing rules derived from the maximization problem (18) are generalizations of the types derived in open-economy TDP models (i.e., with exogenous probabilities of price adjustment). They also represent an open-economy version of the SDP rule of Dotsey, King, and Wolman (1999) and Dotsey and King (2005). However, in contrast to their closed-economy counterpart, value-maximizing firms take into account export demand and the nominal exchange rate and, hence, these factors influence adjustment probabilities.

\subsection{General Equilibrium}

The aggregate state of the economy at time $t$ is a vector $s_{t}=\left(M_{1, t}, M_{2, t}, \Theta_{1, t}, \Theta_{2, t}\right)$, where $M_{i, t}$ represents the exogenous state variables and $\Theta_{i, t}$ represents the period $t$ distribution of producer prices in country $i$. Given the aggregate state, a general equilibrium for the economy is a collection of functions satisfying a set of equilibrium conditions: a collection of allocations for consumers $c_{1}, i_{1}, n_{1}, b_{1}$ and $c_{2}, i_{2}, n_{2}, b_{2}$; a collection of allocations and prices for firms $y_{1}(z), x_{1}(z), n_{1}(z), P_{1,1}(z), P_{1,2}(z)$ and $y_{2}(z), x_{2}(z), n_{2}(z), P_{22}(z), P_{21}(z)$; and a collection of prices $P_{1,1}^{P}, P_{2,1}^{P}, P_{1}^{C}, Q_{1}, W_{1}, D_{1}$ and $P_{2,2}^{P}, P_{1,2}^{P}, P_{2}^{C}, Q_{2}, W_{2}, D_{2}$ such that (i) households maximize their utilities, (ii) firms maximize their values, and (iii) aggregate consistency conditions hold. These aggregate consistency conditions include market-clearing conditions in the goods and labor markets, and in the time-varying distributions of firms in each country.

\section{Solution and Parametrization}

\subsection{Solution}

I use numerical methods to solve the model. First, I compute the steady-state equilibrium by imposing balanced trade to the model's long-run behavior. The model's steady-state equilibrium involves the minimum number of vintages that generate unconditional adjustment by all firms in each country. Second, I take a linear approximation of the behavioral equations around the steady-state and compute the linear rational expectations equilibrium using the algorithm developed by King and Watson (1998). 


\subsection{Parameterization}

Table 1 presents the parameter values for the benchmark economy. I use parameter values generally accepted in the macroeconomic and open-economy literatures. The parameters related to trade are chosen to replicate the relationship between the U.S. and Canada from 1977 to 2005. I chose these two countries because most Canadian trade is done with the U.S. ${ }^{3}$ Hence, any shocks originating from the U.S. is largely transmitted to the Canadian economy through the trade channel, which is the channel of interest in this paper.

The length of a time period is one quarter of a year. The subjective discount factor $\beta$ is 0.99 and implies an annual real rate of return of 4.1 percent. Households devote 20 percent of their time endowment to work. I choose preference parameter values that produce a low elasticity of marginal cost with respect to output by setting the parameter governing the degree of risk aversion $\sigma$ to 0.25 and the parameter governing the elasticity of labor supply $\eta$ to 0.05 . Those parameter values generate a marginal cost elasticity of approximately $0.30{ }^{4}$ The Canadian degree of home bias $\theta_{2}$ is 0.30 , which corresponds to the share of imports in output. Given that the U.S. represents 90 percent of world output, its degree of home bias $\theta_{1}$ is 0.03 . I set the elasticity of substitution between domestic and imported goods $\gamma$ to 1.5.

Labor share in production is 0.65 . The steady-state depreciation rate equals 0.02. Following Baxter and Crucini (1995), I set $\phi=1, \phi^{\prime}=1$ to ensure that the steady state of the model is unaffected by incorporating capital adjustment cost. Given that $\phi=\phi^{\prime}=1$, the elasticity of $i / k$ with respect to movements in Tobin's $q$ is governed by the curvature of the adjustment cost function $\phi^{\prime \prime}$ set to 15 . This value of adjustment cost elasticity implies that investment is about three times as volatile as output in the absence of variable capital utilization. Following Baxter and Farr (2005), I set the elasticity of marginal depreciation to 1.

The variable elasticity demand curves are parameterized by choosing values of $\varphi$ so that demand curves have elasticities of 10 at $d(z) / d=1$. Setting $\gamma$ to 1.02 implies that a 1 percent increase in price decreases demand by 13 percent, which is

\footnotetext{
${ }^{3}$ In 2008, 76 percent of Canadian exports went to the U.S., while 63 percent of Canadian imports were from the U.S.

${ }^{4}$ This feature is necessary to generate real rigidity. Together with menu costs of price adjustment, real rigidities generate price rigidities (see Ball and Romer 1989, and Dotsey and King 2005). Given that the household efficiency condition is $w_{t}=c_{t}^{\sigma} n^{\eta}$, and that consumption and labor are approximately equal to output, the elasticity of marginal cost is approximately equal to $\sigma+\eta$.
} 
somewhere between the response assumed by Kimball (1995) and Bergin and Feenstra (2001). The remaining parameters involve the adjustment-cost distributions which, along with the demand functions, determine the timing and distribution of prices. Table 2 presents the steady-state adjustment hazards and vintage fractions of adjusting firms for each country. The adjustment-cost structure is consistent with microeconomic data on price adjustment that suggest steady-state adjustment hazards are quadratic in log relative price deviations (Caballero and Engle 1993). ${ }^{5}$ The parameter values imply an average age of prices of 1.75 quarters and an expected price duration of 4.05 quarters. Together, the demand and adjustment-cost specifications provide a reasonable approximation of the main features governing the pattern of price adjustments and pricing policies observed in empirical studies such as Bils and Klenow (2004) and Nakamura and Steinsson (2008).

Money supply growth is exogenous and follows an autoregressive process of the form

$$
\Delta M_{i, t}=\rho_{i} \Delta M_{i, t-1}+\varepsilon_{i, t} \text { for } i=1,2,
$$

where $\rho_{i}$ represents the coefficients of autocorrelation and $\varepsilon_{i, t}$ are independently and identically distributed zero-mean disturbances. The value of $\rho_{1}$ is 0.53 for the U.S. and the value of $\rho_{2}$ is 0.42 for Canada. These values come from running a regression on the logarithm of (18) using M1 quarterly data for the U.S. and Canada. The standard deviation of the shocks are 1.63 percent in the U.S. and 2.94 percent in Canada. The cross-correlations of these shocks are chosen to match two moments observed in the data: the correlation between U.S. and Canadian output, and the correlation between U.S. output and the U.S. trade balance. I use the simulated method of moments to find the cross-correlations of these shocks. Finally, I set the steady-state money growth rate to 4 percent, which corresponds to the average inflation rates observed in these countries over the sample period.

\section{Findings}

In this section, I first discuss the SDP model's responses to the 1 percent increase in the U.S. money stock and contrast these responses with those from a TDP model

\footnotetext{
${ }^{5}$ I adopt the cost structure used in Dotsey and King (2005) and set the maximum adjustment cost to 7.5 percent of household production time. This implies that the resources spent adjusting prices relative to sales average 0.8 percent of firms' revenues in the steady state, in line with Levy et al. (1997).
} 
for which the fractions of price-adjusting firms are held fixed at steady-state values. In contrast to the flat adjustment hazards of Calvo (1983), the TDP adjustment hazards are similar to Levin (1991), in which the adjustment probabilities are conditional on the amount of time elapsed since a firm's last price adjustment. To get a better understanding of the mechanism through which money affects international economic activity, I start by exploring the reactions of individual firms to a U.S. monetary expansion in subsection 4.1. In this subsection, I also discuss the amount of exchange rate pass-through to optimal export prices charged by price-adjusting firms, and to aggregate export prices. In subsection 4.2, I discuss the implications for trade and other macroeconomic variables. Then, in subsection 4.3, I look at the business cycle implications of the model in which the world economy experiences shocks to U.S. and Canadian money stocks. In this subsection, I also explore the sensitivity of my findings and highlight the role played by various assumptions about the benchmark SDP model.

\subsection{Firms' Reactions to a U.S. Monetary Expansion}

In this subsection, I look at the firms' reactions to a U.S. monetary expansion. The U.S. monetary expansion is transmitted to firms' profits through a depreciation of the U.S. dollar and a rise in marginal costs generated by an increase in domestic demand. Figure 1 displays the firms' reactions to a U.S. monetary expansion. The top row displays the fractions of price-adjusting firms. The middle rows display the optimal prices chosen by price-adjusting firms for their domestic and export markets. The bottom rows display the corresponding aggregate prices. In order to understand the international transmission mechanism, one needs to understand the pass-through from exchange rate movements to export prices. Table 2 displays the exchange rate pass-through to both, optimal export prices and aggregate export prices. I define the exchange rate pass-through as the percentage change in export prices relative to a change in currency value.

In the TDP model, firms adjust prices on the intensive margin. The monetary expansion causes an increase in U.S. demand and induces U.S. price-adjusting firms to increase both domestic and export prices. I start by looking at the U.S. firms' reactions. The U.S. optimal domestic price jumps on impact and slowly converges to its new long-run value, while the optimal export price increases slightly. On one hand, a depreciation of the U.S. dollar should induce U.S. firms to reduce prices in the Canadian market. On the other, the effect of an expected increase in 
marginal cost induces U.S. firms to increase prices in the Canadian market. These two effects roughly balance out in a TDP environment over the expected horizon of price rigidity. In the current framework, the latter effect dominates and the optimal export price increases little. This generates a negative exchange rate pass-through, both in optimal and aggregate export prices.

Now, let's turn to the behavior of the Canadian firms. The optimal domestic price stays near steady-state value as domestic demand remains nearly constant. However, Canadian firms follow their U.S. counterparts in setting U.S. prices: The optimal export price jumps on impact and slowly converges to its new long-run value. On impact, this generates a change in optimal export prices that is 70 percent higher than the change in currency value. This aggressive price response diminishes over time to reach 8 percent after one year. On aggregate, the amount of exchange rate pass-through is 35 percent on impact and 63 percent after one year.

Firms react differently in the SDP model because they adjust prices on the intensive and extensive margins. For the U.S. domestic market, SDP means that U.S. firms can make small price adjustments now knowing they can choose to increase them later when it is more valuable to do so. Therefore, the optimal domestic price responds little because firms do not want to lose profit by raising prices too aggressively. For the U.S. export market, SDP means that U.S. firms can make bigger profits now by lowering the optimal export price. In contrast to the TDP model, the optimal export price decreases on impact. In fact, the optimal export price drops 15 percent more than the U.S. dollar. On aggregate, this implies an amount of exchange rate pass-through of 28 percent. Over time, the increase in marginal cost takes over and induces firms to adjust prices upward. This becomes obvious four to six quarters after the monetary expansion as the U.S. adjusting fraction and optimal prices deviate further from their long-run values. Ultimately, the collective action of price-adjusting firms feeds into the aggregate price level, and the piling up of prices and actions leads to higher optimal prices.

In turn, movements in U.S. export prices influence Canadian firms' reactions. On impact, the optimal domestic price stays near steady-state value as domestic demand remains nearly constant, while Canadian firms follow their U.S. counterparts in setting U.S. prices. This generates a change in optimal export prices that is 82 percent higher than the change in currency value. As in the TDP model, this aggressive price response diminishes over time to reach 13 percent after one year. 
After a few quarters, higher export demand raises marginal cost and induces firms to adjust prices upward. This becomes obvious eight to ten quarters after the monetary expansion as the Canadian adjusting fraction and optimal prices deviate further from their long-run values.

\subsection{Aggregate Implications to a U.S. Monetary Expansion}

Price movements induced by the domestic monetary expansion affect the aggregate response of the TDP and SDP models in different ways. Figure 2 displays the TDP model's impulse response functions following the U.S. monetary expansion. The model predicts a rise in U.S. output, consumption, and investment. In contrast, Canadian output, consumption, and investment remain close to long-run values: Canadians perceive little change in prices and barely adjust their expenditure decisions. These responses imply a worsening of the U.S. trade balance: Imports increase to fulfill U.S. demand, while exports see little change. Improvements in the trade balance arise as U.S. prices adjust.

The story is different in the SDP model. Figure 3 displays the SDP model's impulse-response functions following a U.S. monetary expansion. The model predicts a rise in U.S. output, consumption, and investment, followed by a contraction of real economic activity. This contraction arises as U.S. prices rise above long-run values. Although the contraction lasts for a substantial amount of time, it does not undo the initial stimulation generated by the monetary expansion. In Canada, output rises on impact to fulfill U.S. demand. The rise in output is followed by a contraction as domestic and export demand fall. Canadian consumption and investment contract because prices rise from their long-run values. These responses imply a worsening of the U.S. trade balance: Imports increase to fulfill U.S. demand, while exports decrease due to falling Canadian demand.

The quantitative implications of the two models for U.S. and Canadian CPI inflation rates are also different. Although both models imply a rising U.S. CPI inflation rate, the SDP model's response is larger. This arises as the piling up of firms' prices and actions leads to higher aggregate prices in the SDP model. The TDP model implies little change in the Canadian CPI inflation rate. In contrast, inflation rises in the SDP model, without any movements in the Canadian money stock. 


\subsection{Business Cycles Analysis}

In this subsection, I look at the business cycle implications of the model. First, I discuss the main features of U.S. and Canadian economic fluctuations as well as trade between the two countries. Second, I take the model to the data by assuming that both countries' money stocks evolve over the business cycle. Finally, I examine the sensitivity of my findings by varying assumptions about the benchmark features.

\subsubsection{The Data}

The U.S. data are from the Bureau of Economic Analysis, with the exception of the monetary aggregate and the quarterly exchange rates, which are from the Board of Governors of the Federal Reserve System. The Canadian data are from Statistics Canada, with the exception of the monetary aggregate, which is from the Bank of Canada. Appendix A offers a more detailed description of the data.

Table 4 presents the business cycle statistics for output, consumption, investment, trade balances, and CPI inflation rates for the U.S. and Canada. The trade balances include only trade between the two countries and are relative to output. Table 5 presents the business cycle statistics for real and nominal exchange rates, as well as for the CPI price ratio. The moments were calculated using a band-pass business-cycle filter that admits frequency components between 6 and 32 quarters. Although the data are from 1974Q1 to 2008Q4, the effective data used in the bandpass statistics are from 1977Q1 to 2005Q4 (see Baxter and King 1999). All the variables were deflated using the implicit price deflators for gross domestic product.

Output, consumption, and investment are procyclical, with consumption being less volatile than output and investment being more volatile than output. The U.S. trade balance is countercyclical, but the Canadian trade balance is procyclical. Both have a volatility much lower than output. CPI inflation rates are procyclical and have a volatility much lower than output. The correlations between U.S. and Canadian output, consumption, investment, and CPI inflation rates are all positive. As for international prices, real and nominal exchange rates are highly correlated and highly volatile relative to output. The CPI price ratio is positively correlated with the real exchange rate and about half as volatile as output. 


\subsubsection{The Benchmark Models}

Tables 4 and 5 present the filtered moments generated by the SDP and TDP models. I assume that both countries' money stocks evolve over the business cycle and that these shocks are the only exogenous shocks in the model. ${ }^{6}$ For each model, the crosscorrelations of the monetary shocks are set to reproduce the correlation between U.S. and Canadian output and the correlation between U.S. output and the U.S. trade balance observed in the data.

The SDP model performs well in terms of predictions for relative volatility, autocorrelation, and correlation with output. In the TDP model, the correlation between Canadian output and the trade balance has the wrong sign, and the correlation between Canadian output and the CPI inflation rate is too strong. Finally, both models capture the positive cross-country correlations of output, consumption, investment, and CPI inflation rates-although the consumption and investment cross-country correlations are higher than the output cross-country correlation in the SDP model.

As for international prices, the relative volatilities of the real and nominal exchange rates with respect to output are too small in both models. The SDP model also predicts a negative correlation between the real and nominal exchange rate, which is contrary to the data. However, the SDP model does a good job matching the dynamics of the CPI price ratio-it does particularly well matching the volatility of this ratio relative to U.S. output and its correlation relative to the real exchange rate.

\subsubsection{Variations on the Benchmark SDP Model}

Finally, I examine the sensitivity of my findings by varying assumptions about three of the SDP model's features. Tables 4 and 5 present the business-cycle moments under the three alternative scenarios: an economy with Dixit-Stiglitz demands ( $\varphi=$ 0 ), an economy without variable capital utilization (but keeping investment), and an economy with a single uncontingent nominal bond.

\footnotetext{
${ }^{6}$ Technology and other types of shocks are important sources of business cycles. However, many papers in the literature, notably Chari et al. (2002), compare their model's moments to those of the data, with movements in money stocks as the only source of exogenous shocks. Thus, I provide this comparison for my own models as a way to compare my results with those in the literature.
} 
The variants with Dixit-Stiglitz demands and without variable capital utilization are able to generate a lower cross-country consumption correlation but perform worst in many other dimensions, notably in terms of CPI inflation rates and trade balance dynamics. As for international prices, the correlation between the real exchange rate and the price ratio has the wrong sign in the variant with Dixit-Stiglitz demands. Finally, the performance of the variant with a single uncontingent nominal bond is roughly similar to the SDP model benchmark with complete financial markets.

\section{Conclusion}

This paper developed a two-country model with SDP in which firms price-discriminate across countries by setting prices in the local currency. I show that a domestic monetary expansion has greater spillover effects to foreign prices and foreign economic activity than an otherwise identical model with TDP. The spillover effects arise because of the interplay between the intensive and extensive margins. This result suggests that the monetary policy implications associated with local-currency pricing are probably specific to the TDP specifications. Next, I look at the implications of the business-cycle moments generated by the models and compared them with moments generated by the data. I find that the SDP model's predictions match the business-cycle moments better than the predictions of the TDP model.

Unfortunately, the SDP model has two caveats relative to other TDP models in the literature. First, by breaking the ability of local-currency pricing to insulate the foreign economy from a domestic monetary shock, the SDP benchmark model loses the ability to generate low cross-country consumption and investment correlations. Second, the SDP model is unable to replicate the dynamics between the real and nominal exchange rates observed in the data. Adding frictions to fix these two caveats is something to investigate in future research. 


\section{A Data}

The data cover the period 1974Q1 to 2008Q4. U.S. data from the Bureau of Economic Analysis are the implicit price deflators for gross domestic product and for private consumption. Gross domestic product, private consumption expenditures, private fixed investment, and exports and imports of goods and services to/from Canada are seasonally adjusted and in billions of U.S. dollars. Canadian data from Statistics Canada are the implicit price deflators for gross domestic product and for private consumption. Gross domestic product, personal consumption expenditures, and business fixed investment are seasonally adjusted and in millions of Canadian dollars. Quarterly averages of the nominal exchange rate and the U.S. monetary aggregate M1, nonseasonally adjusted, are from the Board of Governors of the Federal Reserve System. The Canadian monetary aggregate M1, nonseasonally adjusted, is from the Bank of Canada. Canadian exports and imports of goods and services to/from the U.S. are from the Bureau of Economic Analysis, converted to Canadian dollars using the quarterly nominal exchange rate. 


\section{References}

[1] Ball, L. and Romer, D., 1990. Real Rigidities and the Non-Neutrality of Money. Review of Economic Studies 57, 183-203.

[2] Baxter, M. and Crucini, M. J., 1993. Explaining Saving-Investment Correlations. American Economic Review 83, 416-436.

[3] Baxter, M., and Farr, D. D., 2005. Variable Capital Utilization and International Business Cycles. Journal of International Economics 65, 335-347.

[4] Baxter, M., and King, R.G., 1999. Measuring Business Cycles: Approximate Band-Pass Filters for Macroeconomic Time Series. Review of Economics and Statistics 81, 575-593.

[5] Bergin, P., and Feenstra, R. C., 2001. Pricing-to-Market, Staggered Contracts, and Real Exchange Rate Persistance. Journal of International Economics 54, 333-359.

[6] Betts, C., and Devereux, M.B., 2000. Exchange Rate Dynamics in a Model of Pricing-to-Market. Journal of International Economics 50, 215-244.

[7] Bils, M., and Klenow, P., 2004. Some Evidence on the Importance of Sticky Prices. Journal of Political Economy 112, 947-985.

[8] Bouakez, H., 2005. Nominal Rigidity, Desired Markup Variations, and Real Exchange Rate Persistence. Journal of International Economics 66, 49-74.

[9] Caballero, R., and Engle, E., 1993. Microeconomics Rigidities and Aggregate Price Dynamics. European Economic Review 37, 697-717.

[10] Calvo, G., 1983. Staggered Prices in a Utility-Maximizing Framework. Journal of Monetary Economics 12, 383-398.

[11] Chari, V.V., Kehoe, P.J., and McGrattan, E.R., 2002. Can Sticky Price Models Generate Volatile and Persistent Real Exchange Rates? Review of Economic Studies 69, 533-564.

[12] Dotsey, M., and King, R.G., 2005. Implication of State-Dependent Pricing for Dynamic Macroeconomic Models. Journal of Monetary Economics - CarnegieRochester Series on Public Policy 52, 213-242. 
[13] Dotsey, M., King, R.G., and Wolman, A.L., 1999. State-Dependent Pricing and the General Equilibrium Dynamics of Money and Output. Quarterly Journal of Economics 114, 655-690.

[14] Floden, M. and Wilander, F., 2006. State-Dependent Pricing, Invoicing Currency, and Exchange Rate Pass-Through. Journal of International Economics 70, 178-196.

[15] Gopinath, G., Itskhoki, O, and Rigobon, R., 2009. Currency Choice and Exchange Rate Pass-Through. American Economic Review, forthcoming.

[16] Gopinath, G., and Itskhoki, O., 2009. Frequency of Price Adjustment and PassThrough. Quarterly Journal of Economics, forthcoming.

[17] Gust, C., Leduc, S., and Vigfusson, R.J., 2006. Trade Integration, Competition, and the Decline in Exchange-Rate Pass-Through. International Finance Discussion Paper 864.

[18] Kimball, M.S., 1995. The Quantitative Analytics of the Basis Neomonetarist Model. Journal of Money, Credit, and Banking 27, 1241-1277.

[19] King, R.G., and Watson, M.W., 1998. The Solution of Singular Linear Difference Systems Under Rational Expectations. International Economic Review 39, 1015-1026.

[20] Kollmann, R., 2001. The Exchange Rate in a Dynamic-Optimizing Business Cycle Model with Nominal Rigidities: A Quantitative Investigation. Journal of International Economics, 243-262.

[21] Landry, A., 2009. Expectation and Exchange-Rate Dynamics: A StateDependent Pricing Approach. Journal of International Economics 78, 60-71.

[22] Levin, A., 1991. The Macroeconomic Significance of Nominal Wage Contract Duration. Discussion paper 91-08, University of California at San Diego.

[23] Levy, D., Bergen, M., Dutta, S., and Venable, S., 1997. The Magnitude of Menu Costs: Direct Evidence from a Large U.S. Supermarket Chain. Quarterly Journal of Economics 112, 791-825.

[24] Nakamura, E., and Steinsson, J., 2008. Five Facts About Prices: A Reevaluation of the Menu Cost Models. Quarterly Journal of Economics 123, 1415-1464. 
Table 1: Parameter values

\begin{tabular}{|c|c|c|c|}
\hline \multicolumn{2}{|c|}{ Preferences } & \multirow{2}{*}{$\begin{array}{l}\text { U.S. } \\
0.99\end{array}$} & \multirow{2}{*}{$\begin{array}{c}\text { Canada } \\
0.99\end{array}$} \\
\hline$\beta$ & Discount rate & & \\
\hline$\sigma$ & Intertemporal elasticity of substitution & 0.25 & 0.25 \\
\hline$n$ & Fraction of time working & 0.20 & 0.20 \\
\hline$\eta$ & Elasticity of labor supply & 0.05 & 0.05 \\
\hline \multicolumn{4}{|c|}{ Trade } \\
\hline$\theta_{i}$ & Degree of home bias & 0.03 & 0.30 \\
\hline$\gamma$ & Elasticity of substitution between domestic and imported goods & 1.5 & 1.5 \\
\hline \multicolumn{4}{|c|}{ Investment } \\
\hline$\varsigma$ & Labor share & 0.65 & 0.65 \\
\hline$\delta$ & Depreciation rate & 2 & 2 \\
\hline $1 / \phi$ & Elasticity of investment & 15 & 15 \\
\hline$\xi$ & Elasticity of marginal depreciation & 1 & 1 \\
\hline \multicolumn{4}{|c|}{ Demand } \\
\hline$\varrho$ & Elasticity of demand & 10 & 10 \\
\hline$\phi$ & Demand curvature & 1.02 & 1.02 \\
\hline \multicolumn{4}{|c|}{ Monetary policy } \\
\hline \multirow[t]{2}{*}{$\rho_{i}$} & Money growth autocorrelation & 0.53 & 0.42 \\
\hline & Standard deviation of the shocks & 0.13 & 0.01 \\
\hline
\end{tabular}


Table 2: Adjustment hazard and vintage fractions

\begin{tabular}{cccccccccc}
\hline & \multicolumn{8}{c}{ Quarter(s) since last adjustment } \\
\cline { 3 - 9 } & & 0 & 1 & 2 & 3 & 4 & 5 & 6 \\
\cline { 3 - 9 }$\alpha_{j}$ & Adjustment hazard & $\mathrm{N} / \mathrm{A}$ & 0.035 & 0.112 & 0.221 & 0.383 & 0.650 & 1 \\
$\omega_{j}$ & Vintage fractions & 0.247 & 0.239 & 0.212 & 0.165 & 0.102 & 0.036 & $\mathrm{~N} / \mathrm{A}$
\end{tabular}




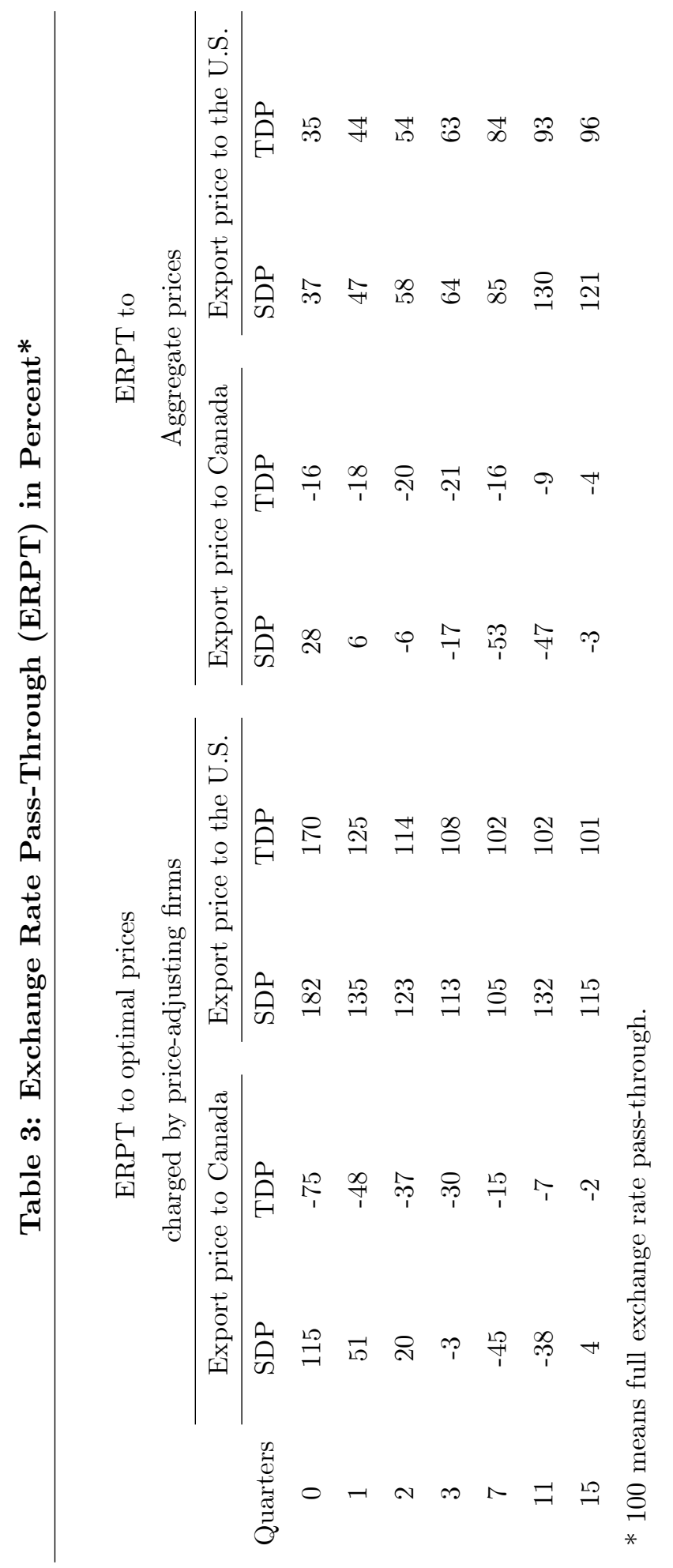




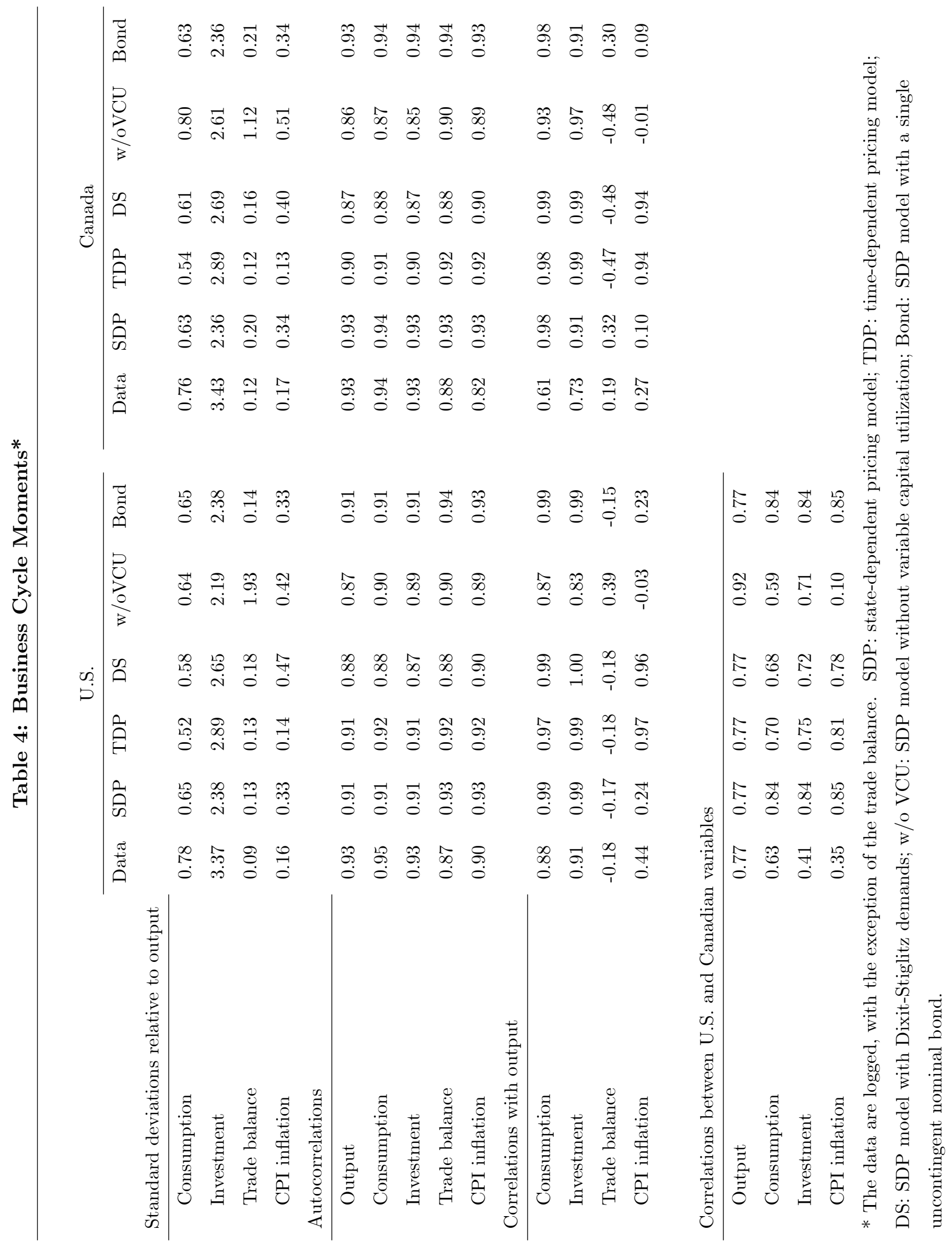


Table 5: Exchange Rates and Prices*

\begin{tabular}{|c|c|c|c|c|c|c|}
\hline & Data & SDP & TDP & DS & $\mathrm{w} / \mathrm{oVCU}$ & Bond \\
\hline \multicolumn{7}{|c|}{ Standard deviations relative to U.S. output } \\
\hline Real exchange rate & 2.26 & 0.09 & 0.11 & 0.13 & 0.28 & 0.06 \\
\hline Nominal exchange rate & 2.39 & 0.48 & 0.37 & 0.99 & 1.24 & 0.46 \\
\hline Price ratio & 0.54 & 0.50 & 0.34 & 0.98 & 1.29 & 0.49 \\
\hline \multicolumn{7}{|l|}{ Autocorrelations } \\
\hline Real exchange rate & 0.94 & 0.89 & 0.91 & 0.88 & 0.87 & 0.87 \\
\hline Nominal exchange rate & 0.94 & 0.94 & 0.96 & 0.95 & 0.93 & 0.94 \\
\hline Price ratio & 0.93 & 0.94 & 0.97 & 0.95 & 0.92 & 0.93 \\
\hline \multicolumn{7}{|c|}{ Correlations with the real exchange rate } \\
\hline Nominal exchange rate & 0.97 & -0.17 & 0.43 & 0.18 & -0.07 & -0.48 \\
\hline Price ratio & 0.35 & 0.34 & -0.14 & -0.04 & 0.28 & 0.58 \\
\hline
\end{tabular}



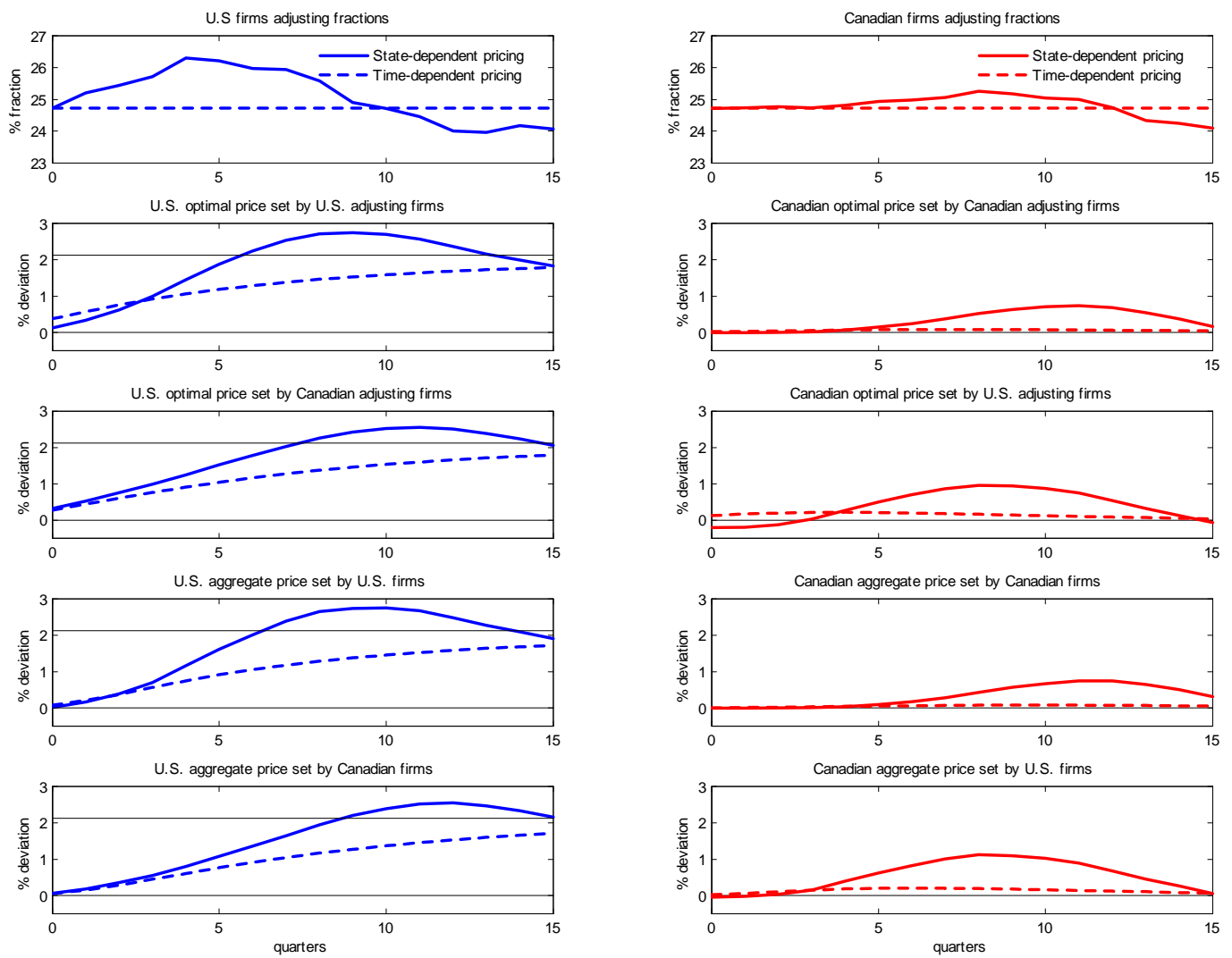

Figure 1: Firms' reactions to a U.S. monetary expansion. Note: U.S. variables in blue and Canadian variables in red. 

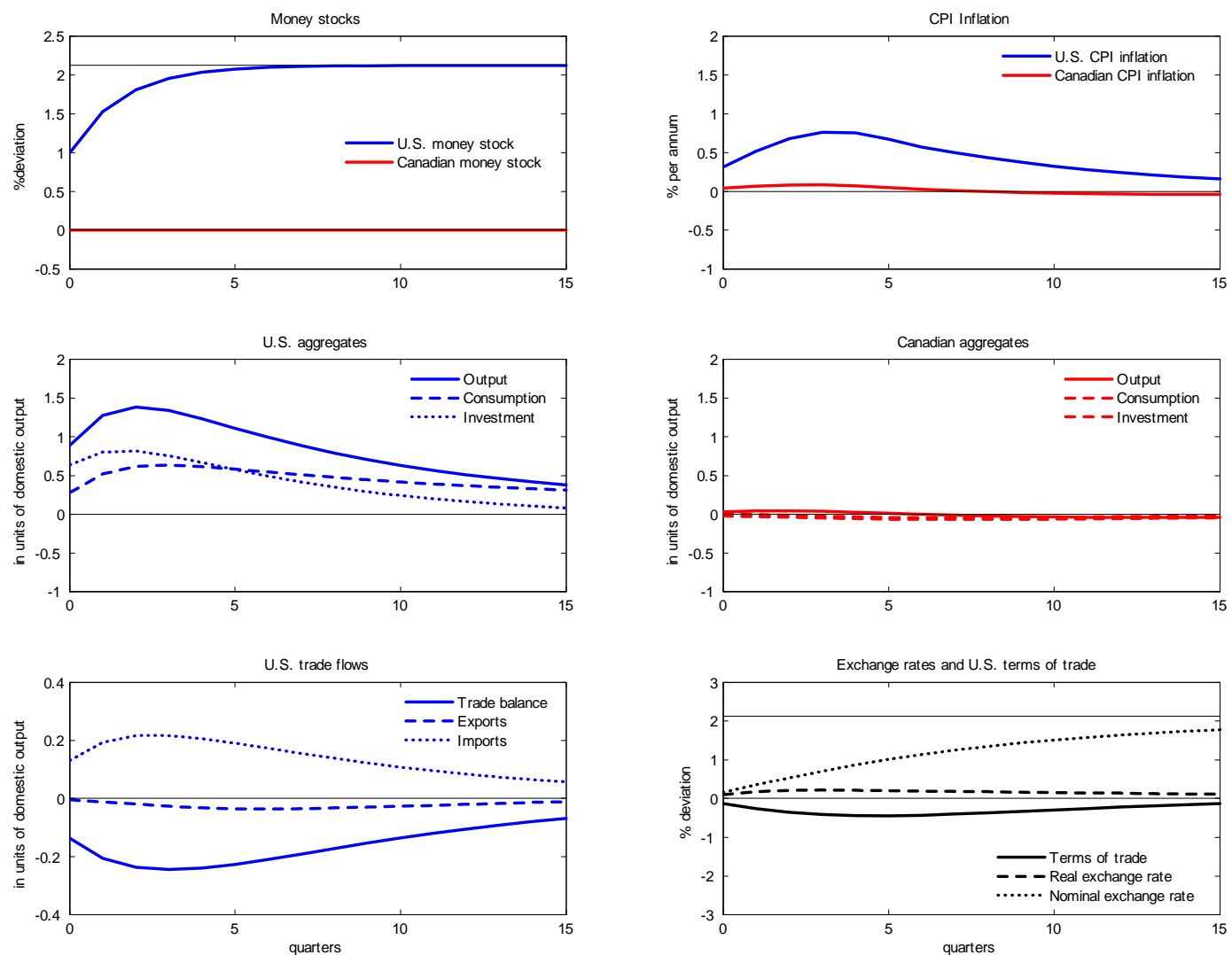

Figure 2: Aggregate implications with time-dependent pricing model. Note: U.S. variables in blue and Canadian variables in red. 

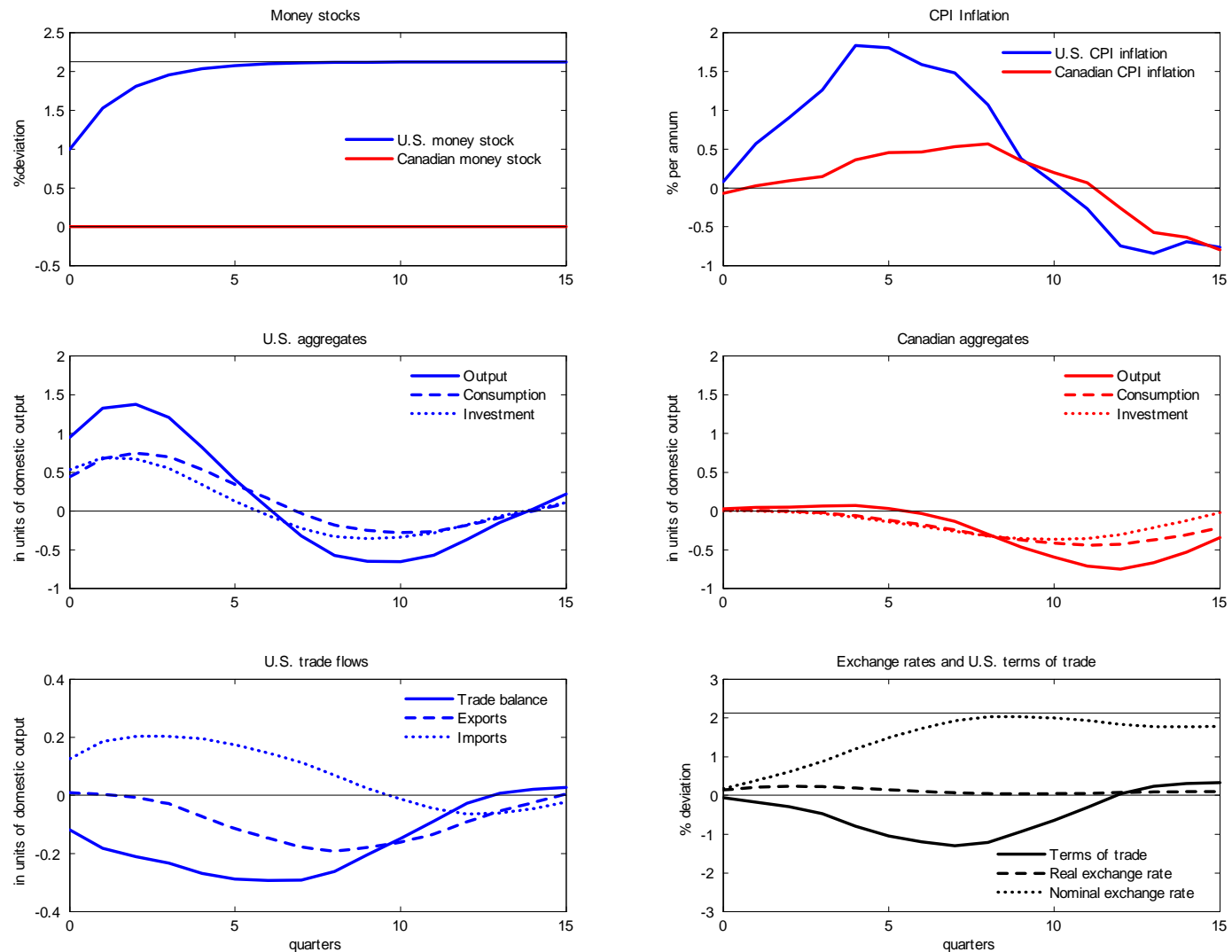

Figure 3: Aggregate implications with state-dependent pricing model. Note: U.S. variables in blue and Canadian variables in red. 